JURNAL PENDIDIKAN, p-ISSN 2715-095X, e-ISSN 2686-5041

Volume 30, No.3, Nopember 2021 (489-498)

Online: http://journal.univetbantara.ac.id/index.php/jp

\title{
Pengaruh Kreativitas dan Motivasi terhadap Kemandirian Belajar siswa kelas X di SMA Kristen Satya Wacana Salatiga
}

\author{
Vika Noviana Safitri \\ Program Studi Pendidikan Ekonomi, Fakultas Keguruan Dan Ilmu Pendidikan \\ Universitas Kristen Satya Wacana, Email: Vikasafitri13@gmail.com
}

Received: September 22, $2021 \quad$ Accepted: Oktober 18, $2021 \quad$ Online Published: Nopember 08, 2021

\begin{abstract}
Abstrak: Tujuan penelitian ini adalah untuk mengetahui pengaruh kreativitas dan motivasi terhadap kemandirian belajar diSMA Kristen Satya Wacana Salatiga. Penelitian ini menggunakan metode Asosiatif dengan pendekatan kuantitatif. Teknik yang digunakan adalah pengumpulan data (angket). Analisis data menggunakan regresi linier berganda $\mathrm{Y}=36.706$ $0,143\left(\mathrm{X}_{1}\right)+0,265\left(\mathrm{X}_{2}\right)$ berdasarkan analisis dan pembahasan dapat disimpulkan bahwa :1) Tidak terdapat pengaruh antara Kreativitas $\left(\mathrm{X}_{1}\right)$ terhadap Kemandirian Belajar (Y). 2) Terdapat pengaruh antara Motivasi $\left(\mathrm{X}_{2}\right)$ terhadap Kemandirian Belajar (Y). 3.) Terdapat pengaruh antara Kreativitas $\left(\mathrm{X}_{1}\right)$ dan Motivasi $\left(\mathrm{X}_{2}\right)$ terhadap Kemandirian Belajar $(\mathrm{Y})$. Hal ini berarti bahwa kreativitas tidak memberikan kontribusi terhadap kemandirian belajar sedangkan motivasi memberikan kontribusi dalam peningkatan kemandirian belajar.
\end{abstract}

Kata-kata Kunci: Kreativitas, Motivasi, dan Kemandirian Belajar.

\section{The Influence of Creativity and Motivation on Independent Learning of Grade X Students at SMA Kristen Satya Wacana Salatiga}

\section{Vika Noviana Safitri}

\author{
Program Studi Pendidikan Ekonomi, Fakultas Keguruan Dan Ilmu Pendidikan \\ Universitas Kristen Satya Wacana, Email: Vikasafitri13@gmail.com
}

\begin{abstract}
The purpose of this study was to determine the effect of creativity and motivation on learning independence at Satya Wacana Christian Senior High School, Salatiga. This study used an associative method with a quantitative approach. The technique used is data collection (questionnaire). Data analysis using multiple linear regression $Y=36.706-0.143\left(X_{I}\right)+0.265$ $\left(X_{2}\right)$ based on the analysis and discussion it can be concluded that: 1) There is no influence between Creativity $\left(X_{1}\right)$ on Independence Learning (Y). 2) There is an influence between Motivation $\left(X_{2}\right)$ on Independent Learning (Y). 3.) There is an influence between Creativity $\left(X_{1}\right)$ and Motivation $\left(\mathrm{X}_{2}\right)$ on Independence Learning $(Y)$. This means that creativity does not contribute to learning independence while motivation contributes to increasing learning independence.

Keywords : Kreativitas, Movivasi, dan Kemandirian Belajar
\end{abstract}

\section{Pendahuluan}

Pendidikan merupakan salah satu sarana penting untuk meningkatkan kualitas Sumber Daya Manusia Indonesia. Melalui pendidikan diharapkan mampu menuntut ilmu secara spesifik dan terperinci serta dapat mengaplikasikan ilmu tersebut dalam kehidupan sehari-hari, sehingga dapat tercipta manusia berkualitas yang mampu menghadapi 
persaingan global. Meningkatkan kualitas Sumber Daya Manusia Indonesia salah satunya yaitu dengan belajar mandiri. Menurut Mudjiman (2007:7) Kemandirian Belajar dapat diartikan sebagai sifat serta kemampuan yang dimiliki siswa untuk melakukan kegiatan belajar aktif yang didorong oleh motif menguasai sesuatu kompetensi yang telah dimiliki. Siswa diharap memiliki kemandirian belajar yang didorong oleh niat dan motif dengan menguasai kompetensi yang telah dimiliki akan percaya diri dalam memecahkan masalahnya dan bertanggung jawab pada setiap proses belajar. Kreativitas adalah memodifikasi sesuatu yang sudah ada menjadi konsep baru dengan kata lain, terdapat dua konsep lama yang dikombinasikan menjadi suatu konsep baru, Setiawan (2009:44). Berarti bahwa apa yang dihasilkan atau diciptakan tidak perlu atau mesti yang baru sama sekali. Kreativitas ialah salah satu faktor dalam kemandirian belajar siswa. Kreativitas tidak hanya sekedar keberuntungan bagi siswa tapi merupakan kerja keras yang didasari oleh para siswa. Salah satu faktor pendukung dalam kemandirian belajar ialah Motivasi. Menurut Sardiman (2007:75) motivasi ialah keseluruhan data penggerak di dalam diri peserta didik yang menimbulkan kegiatan belajar, yang menjamin kelangsungan dari kegiatan belajar, sehingga tujuan yang dikehendaki oleh subyek belajar itu tercapai. Adanya suatu motivasi belajar maka juga akan mendorong timbulnya kemandirian belajar siswa, karena dengan mempunyai suatu motivasi seorang siswa terdorong oleh adanya semangat dan gairah untuk merubah sikap mandiri. Kemandirian juga dapat dijadikan sebagai salah satu indikator pencapaian keberhasilan dalam upaya untuk mencapai hasil belajar yang memuaskan maka perlu ditumbuhkan dan dikembangkannya kemandirian anak yang tentunya didorong oleh adanya motivasi untuk belajar dan memiliki kreativitas dalam belajar (Suwarto, 2013, 2017). Masalah pada umumnya yang sering dijumpai dikalangan siswa yaitu kehilangan semangat belajar saat menemui kesulitan memahami materi pada mata pelajaran yang diajarkan. Kemampuan dan memahami materi pada mata pelajaran berbeda antara siswa dengan siswa lainnya. Mereka lebih cenderung suka memperoleh hasil nilai seperti copy paste tugas yang diberikan oleh guru dan mencontek saat ujian. Berdasarkan observasi awal yang dilakukan diSMA Kristen Satya Wacana, masih ditemukan ada siswa yang cepat merasa bosan dan tidak memperhatikan materi yang disampaikan oleh guru. Keaktifan siswa di kelas juga menurun misalkan ketika diberikan tugas ada yang tertidur dan ada yang sibuk mengobrol dengan temannya. Saat ujian masih ada yang mencontek satu sama lain dan akhirnya mereka hanya mendapatkan hasil yang kurang memuaskan atau kurang maksimal seperti nilai yang menurun dan tidak memperoleh prestasi di dalam kelas sehingga mendapatkan teguran, baik dari guru maupun orang tua. Kreativitas menurut Semiawan (2009:44) adalah modifikasi sesuatu yang sudah ada menjadi konsep baru. Dengan kata lain, terdapat konsep lama yang dikombinasikan dengan konsep baru. Menurut Chaplin dalam Yeni Rachmawati (2011:14) mengutarakan bahwa kreativitas merupakan kemampuan menghasilkan bentuk baru dalam seni, atau dalam permesinan, atau dalam memecahkan masalah-masalah dengan metode baru. Menurut Munandar (2009:12) bahwa kreativitas adalah hasil interaksi antara individu dan lingkungannya, kemampuan untuk membuat kombinasi baru berdasarkan data, informasi, atau unsur-unsur yang sudah ada atau dikenal sebelumnya yaitu semua pengalaman dan pengetahuan yang telah diperoleh seseorang selama hidupnya baik itu dilingkungan sekolah, keluarga, maupun dari lingkungan masyarakat. Menurut Semiawan ciri-ciri kreativitas sebagai berikut: (1) Dorongan ingin tahu besar. (2) Sering mengajukan pertanyaan yang baik. (3) Memberikan banyak gagasan atau usul terhadap suatu masalah. (4) Bebas dalam menyatakan pendapat sendiri dan dapat mengungkapkannya. (5) Tidak mudah terpengaruh dengan orang lain. (6) 
Daya imajinasi kuat. (7) Dapat kerja sendiri. (8) Senang mencoba hal-hal baru. Ada beberapa faktor yang mempengaruhi kreativitas anak. Menurut Setiawan (2009:56) bahwa faktor yang mempunyai kreativitas siswa adalah iklim dan suasana yang menunjang pemikiran kreatif seperti bersikaplah terbuka, mempunyai waktu untuk memikirkan dan mengembangkan ide tau gagasan kreatif, suasana yang hangat dan mendukung memberi keamanan dan kebebasan untuk berpikir menyelidiki (eksploratif) memberi kesempatan kepada anak untuk berperan serta dan mengambil keputusan terlibat dan mendukung gagasan atau pemecahan masalah. Berdasarkan pengertian kreativitas dari para ahli diatas, dapat diartikan bahwa kreativitas adalah memodifikasi sesuatu yang sudah ada menjadi konsep baru dengan metode baru untuk memecahkan suatu masalah berdasarkan data,informasi, semua pengalaman, dan pengetahuan yang telah diperoleh seseorang selama hidupnya baik itu dilingkungan sekolah, keluarga, maupun dilingkungan masyarakat. Faktor yang mempengaruhi kreativitas siswa yaitu kondisi internal, iklim dan suasana yang menunjang pemikir kreatif seperti rasa ingin tau, percaya diri, bersikap terbuka, mengembangkan idea atau gagasan baru serta memberi kesempatan dan kebebasan berpikir kepada anak untuk mengambil keputusan dalam memecahkan suatu masalah. Menurut Sardiman (2007:75) motivasi ialah keseluruhan data penggerak di dalam diri peserta didik yang menimbulkan kegiatan belajar, yang menjamin kelangsungan dari kegiatan belajar, sehingga tujuan yang dikehendaki oleh subyek belajar itu tercapai. Menurut Vroom (2007:147) motivasi ialah sebuah hasil yang ingin diraih atau dicapai oleh seseorang dan sebuah perkiraan bahwa apa yang dilakukannya akan mengarah pada hasil yang diinginkannya. Menurut Rivai dan Sagala (2009:837) motivasi adalah serangkaian sikap dan nilai-nilai yang mempengaruhi individu untuk mencapai hal yang spesifik sesuai dengan tujuan individu. Sikap dan nilai tersebut memberikan kekuatan untuk mendorong individu bertingkah laku dalam mencapai tujuan. Menurut Sardiman (2007:83) ciri-ciri motivasi sebagai berikut: (1) Tekun menghadapi tugas (dapat mengerjakan tugas terus menerus dalam waktu yang lama, tidak berhenti sebelum selesai). (2) Ulet menghadapi kesulitan (tidak lekas putus asa, tidak cepat puas dengan hasil yang telah dicapai). (3) Menunjukkan minat terhadap bermacam-macam masalah. (4) Cepat bosan pada tugas yang rutin (hal-hal yang bersifat mekanis, berulang-ulang begitu saja, sehingga kurang kreatif). (5) Lebih senang bekerja mandiri. (6) Dapat mempertahankan pendapatnya. (7) Tidak mudah melepaskan hal-hal yang diyakini. (7) Senang mencari dan memecahkan masalah soal-soal. Menurut Uno (2011:23) motivasi dapat timbul karena faktor intrinsik dan ekstrinsik. (1) Faktor intrinsik yang mempengaruhi motivasi yaitu "pertama, hasrat dan keinginan berhasil dan dorongan kebutuhan belajar, dan kedua, harapan akan cita-cita". Faktor ekstrinsik yang mempengaruhi motivasi meliputi "pertama adanya penghargaan, kedua, lingkungan belajar yang kondusif, dan ketiga, kegiatan belajar yang menarik". Meraih motivasi yang tinggi bagi siswa, harus diperhatikan faktor yang mempengaruhinya baik intrinsik maupun ekstrinsik. Siswa harus menyadari dengan sengaja untuk melakukan kegiatan dan kebutuhan belajar untuk meraih tujuan (cita-cita yang hendak dicapai). (2) Faktor ekstrinsik harus disertai penghargaan (pujian) jika siswa berprestasi, diperlukan lingkungan belajar yang kondusif dan kegiatan belajar yang menarik. Dalam hal ini peran orang tua diperlukan untuk menciptakan suasana yang kondusif dan membantu anaknya 
dalam belajar. Berdasarkan pengertian motivasi para ahli diatas, dapat diartikan bahwa motivasi ialah keseluruhan data penggerak di dalam peserta didik yang menimbulkan kegiatan belajar dan kelangsungan dari kegiatan belajar dengan memberikan kekuatan untuk mendorong individu bertingkah laku dalam mencapai tujuan. Faktor yang mempengaruhi faktor Intrinsik (hasrat dan keinginan berhasil dan dorongan kebutuhan belajar serta harapan akan cita-cita dan faktor ekstrinsik (penghargaan) yang meliputi seperti tekun menghadapi tugas, ulet menghadapi kesulitan, minat terhadap bermacammacam masalah, lebih senang bekerja mandiri, tidak mudah melepaskan hal-hal yang diyakini, senang mencari dan memecahkan masalah soal-soal. Pengertian belajar menurut Uno (2011:51) yaitu metode belajar dengan kecepatan sendiri, tanggung jawab sendiri, dan belajar yang berhasil. Sehingga berhasil tidaknya dalam belajar semuanya ditentukan oleh diri sendiri. Menurut Mudjiman (2011:1-2) belajar mandiri merupakan kegiatan belajar aktif, yang didorong oleh motif untuk menguasai suatu kompetensi yang telah dimiliki. Dalam penetapan kompetensi ini meliputi tujuan belajar dan cara pencapaiannya baik penetapan waktu belajar, tempat belajar, tempo belajar, cara belajar, sumber belajar, maupun evaluasi hasil belajar dilakukan sendiri. Menurut Umar Tirta Raharja dan La Sulo (2000:50) kemandirian belajar diatikan sebagai aktivitas belajar yang berlangsung nya lebih didorong oleh kemampuan sendiri, pilihan sendiri, dan tanggung jawab sendiri oleh pembelajar. Pada umumnya, kemandirian belajar lebih menekankan individu untuk belajar tanpa tergantung dengan orang lain, tanggung jawab, dan mampu mengontrol dirinya sendiri. Belajar mandiri menurut Mudjiman (2011:14) juga disebut sebagai belajarnya orang dewasa, karena cara belajarnya secara mandiri. Adapun ciri-ciri belajar mandiri menurut Mudjiman (2011:9-10) diantaranya terdiri dari kegiatan belajar mengarahkan diri sendiri atau tidak tergantung pada orang lain, mampu menjawab pertanyaan saat pembelajaran bukan karena bantuan guru atau lainnya, lebih suka aktif daripada pasif, memiliki kesadaran apa yang harus dilakukan, evaluasi belajar dilaksanakan bersama-sama, belajar dengan mengaplikasikan (action), pembelajaran yang berkolaborasi artinya memanfaatkan pengalaman dan bertukar pengalaman, pembelajaran yang berbasis masalah dan selalu mengharapkan manfaat yang dapat diaplikasikan dalam kehidupan. Menurut Syam (2005:10), ada dua faktor yang mempengaruhi kemandirian belajar yaitu sebagai berikut: Pertama, faktor internal dengan indikator tumbuhnya kemandirian belajar yang terpancar dalam fenomena antara lain: (a) Sikap bertanggung jawab untuk melaksanakan apa yang dipercayakan dan ditugaskan. (b) Kesadaran hak dan kewajiban siswa disiplin moral yaitu dengan tingkah laku yang baik. (c) Kedewasaan diri mulai konsep diri, motivasi sampai berkembangnya pikiran, karsa, cipta dan karya (secara berangsur). (d) Kesadaran mengembangkan kesehatan dan kekuatan jasmani, rohani dengan makanan yang sehat, kebersihan dan olahraga. (e) Disiplin diri dengan mematuhi tata tertib yang berlaku, sadar hak dan kewajiban. Keselamatan lalu lintas, menghormati orang lain, dan melaksanakan kewajiban. Kedua, faktor eksternal sebagai pendorong kedewasaan dan kemandirian belajar meliputi: potensi jasmani rohani yaitu tubuh yang sehat dan kuat, lingkungan hidup, dan sumber daya alam, social ekonomi, keamanan dan ketertiban yang mandiri, kondisi dan suasana keharmonisan dalam dinamika positif atau negatif sebagai peluang dan tantangan meliputi tatanan budaya dan sebagainya secara kumulatif. Pengukuran dalam kemandirian belajar mengandung pengertian suatu keadaan ketika seseorang memiliki hasrat bersaing untuk maju demi kebaikan dirinya, mampu mengambil keputusan dan inisiatif untuk mengatasi masalah yang dihadapi, memiliki kepercayaan diri dalam mengerjakan tugasnya dan bertanggung jawab terhadap apa yang telah dilakukan. 
Pengukuran kemandirian belajar pada penelitian ini berdasarkan pada faktor internal (dari dalam diri) siswa yaitu tanggung jawab, inisiatif, disiplin, motivasi,dan percaya diri. Dari beberapa definisi diatas, maka dapat diartikan bahwa kemandirian belajar merupakan sikap individu khususnya siswa dalam suatu pembelajaran yang mampu untuk menguasai kompetensi, tanpa tergantung dengan orang lain serta bertanggung jawab terhadap dirinya. Secara individu seseorang yang memiliki kemandirian belajar memiliki sifat percaya diri, motivasi, disiplin, inisiatif, dan tanggung jawab. Siswa tidak bergantung kepada orang lain dan mampu mendisiplinkan dirinya sendiri. Kemandiran belajar yang seperti ini sangat diperlukan siswa agar pencapaian prestasi belajar dapat optimal.

\section{Metode Penelitian}

Jenis penelitian yang digunakan dalam penelitian ini adalah penelitian asosiatif dengan pendekatan kuantitatif. Penelitian ini bertujuan untuk mengetahui pengaruh kreativitas dan motivasi terhadap kemandirian belajar. Subjek dalam penelitian ini adalah siswa SMA Kristen Satya Wacana dengan jumlah 85 orang siswa. Objek penelitian adalah kreativitas,motivasi dan kemandirian belajar Populasi penelitian ini adalah siswa kelas $\mathrm{X}$ dengan ketetapan sampel 85 orang, yang diambil menggunakan Skala Likert. Data dikumpulkan dengan teknik angket yang telah diukur tingkat validitas dan reliabilitasnya. Angket digunakan untuk memberi seperangkat pertanyaan atau pernyataan tertulis kepada responden untuk dijawabnya. Analisis data menggunakan teknik analisis regresi linier berganda dengan kriteria signifikansi sebesar 5\% atau 0,05, untuk memprediksi besaran kontribusi variable $\mathrm{X}$ terhadap variable $\mathrm{Y}$. Uji asumsi atas penerapan teknik analisis tersebut meliputi Normalitas, Linearitas, Multikolinearitas, dan Heteroskedastisitas.

\section{Hasil Penelitian}

Tabel 1. Hasil analisis regresi berganda

Coefficientsa

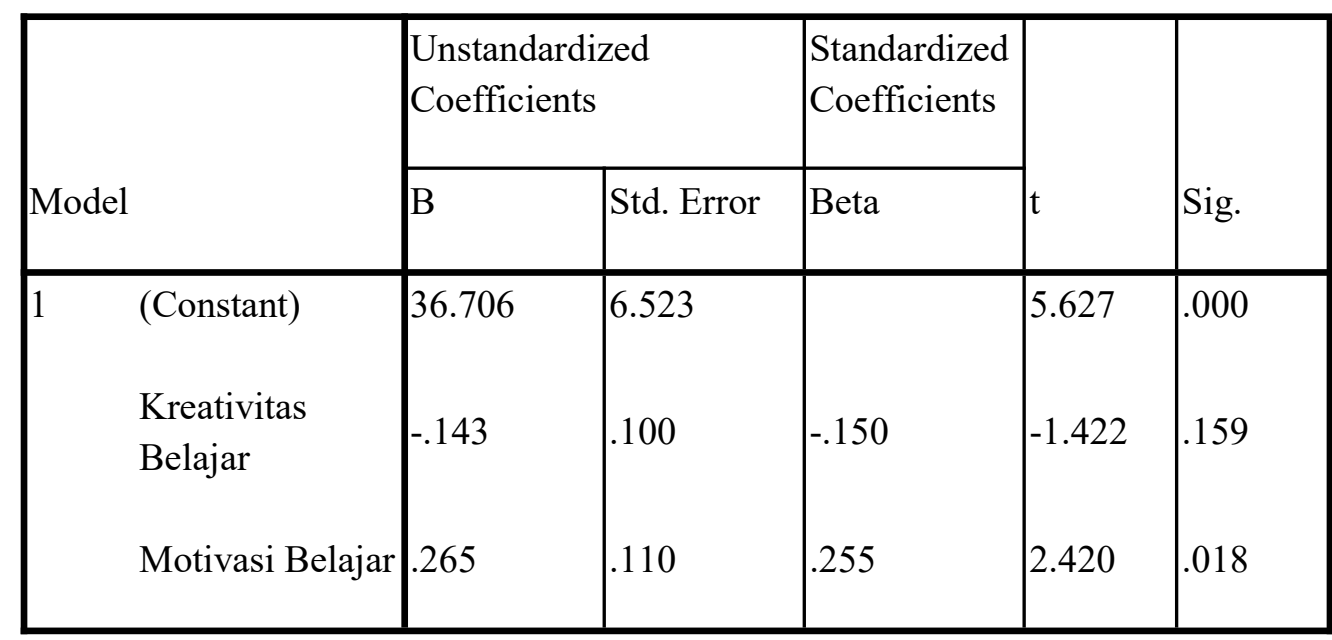

a. Dependent Variable: Kemandirian Belajar 
Dari hasil perhitungan tersebut maka persamaan regresi adalah sebagai berikut :

$$
\mathrm{Y}=36.706-0,143\left(\mathrm{X}_{1}\right)+0,265\left(\mathrm{X}_{2}\right)
$$

(1) Persamaan regresi diatas variable Kemandirian Belajar (Y) adalah sebesar 36.706 yang artinya jika tidak ada perubahan variable Kreativitas $\left(\mathrm{X}_{1}\right)$ dan Motivasi $\left(\mathrm{X}_{2}\right)$ maka Kemandirian Belajar tetap 36.706. (2) Persamaan regresi diatas menyatakan bahwa variable Kreativitas $\left(\mathrm{X}_{1}\right)$ berpengaruh negatif terhadap Kemandirian belajar (Y) . Artinya jika variable lain nilai tetap dan Kreativitas mengalami peningkatan 1\% maka Kreativitas naik maka kemandirian belajar akan menurun, begitu sebaliknya. (3) Persamaan regresi diatas menyatakan variable Motivasi $\left(\mathrm{X}_{2}\right)$ berpengaruh positif terhadap kemandirian belajar (Y).Artinya jika variable lain nilai tetap dan Motivasi mengalami peningkatan 1\%, maka Motivasi naik sedangkan kemandirian belajar akan naik, begitu sebaliknya.

Tabel 2. Hasil uji t

\section{Coefficients $^{\mathrm{a}}$}

\begin{tabular}{|c|c|c|c|c|c|c|}
\hline \multirow{2}{*}{\multicolumn{2}{|c|}{ Model }} & \multicolumn{2}{|c|}{ Unstandardized Coefficients } & \multirow{2}{*}{$\begin{array}{c}\begin{array}{c}\text { Standardized } \\
\text { Coefficients }\end{array} \\
\text { Beta }\end{array}$} & \multirow[b]{2}{*}{$\mathrm{t}$} & \multirow[b]{2}{*}{ Sig. } \\
\hline & & B & Std. Error & & & \\
\hline \multirow[t]{3}{*}{1} & (Constant) & 36.706 & 6.523 & & 5.627 & .000 \\
\hline & Kreativitas & -.143 & .100 & -.150 & -1.422 & .159 \\
\hline & Motivasi & .265 & .110 & .255 & 2.420 & .018 \\
\hline
\end{tabular}

a. Dependent Variable: Kemandirian

Diketahui nilai signifikansi (Sig) variable Kreativitas adalah 0,159. Karena nilai Sig. 0,159 lebih besar dari 0,05, maka sesuai dasar pengambilan keputusan dalam uji t dapat disimpulkan bahwa hipotesis ditolak atau dengan kata lain tidak ada pengaruh Kreativitas terhadap Kemandirian Belajar. Diketahui nilai signifikansi (Sig. ) variable Motivasi adalah 0,018. Karena nilai Sig. 0,018 lebih kecil dari 0,05, maka sesuai dasar pengambilan keputusan dalam uji t dapat disimpulkan bahwa hipotesis diterima atau dengan kata lain terdapat pengaruh Motivasi terhadap Kemandirian Belajar. Berdasarkan perbandingan nilai hitung $t$ dan nilai $t$ tabel. Diketahui nilai t hitung variable Kreativitas adalah $-1,422$. Karena nilai $\mathrm{t}$ hitung -1,422 lebih kecil dari t table 1,989, maka sesuai dengan dasar pengambilan keputusan berdasarkan uji t dapat disimpulkan bahwa hipotesis ditolak atau dengan kata lain tidak ada pengaruh Kreativitas terhadap Kemandirian Belajar. (2) Nilai t hitung variable Motivasi adalah 2,420. Karena nilai t hitung 2,420 lebih besar dari t table 1,989, maka sesuai dengan dasar pengambilan keputusan berdasarkan uji t dapat disimpulkan bahwa hipotesis diterima atau dengan kata lain ada pengaruh Motivasi terhadap Kemandirian Belajar. 
Tabel 3. Hasil uji F

ANOVA $^{b}$

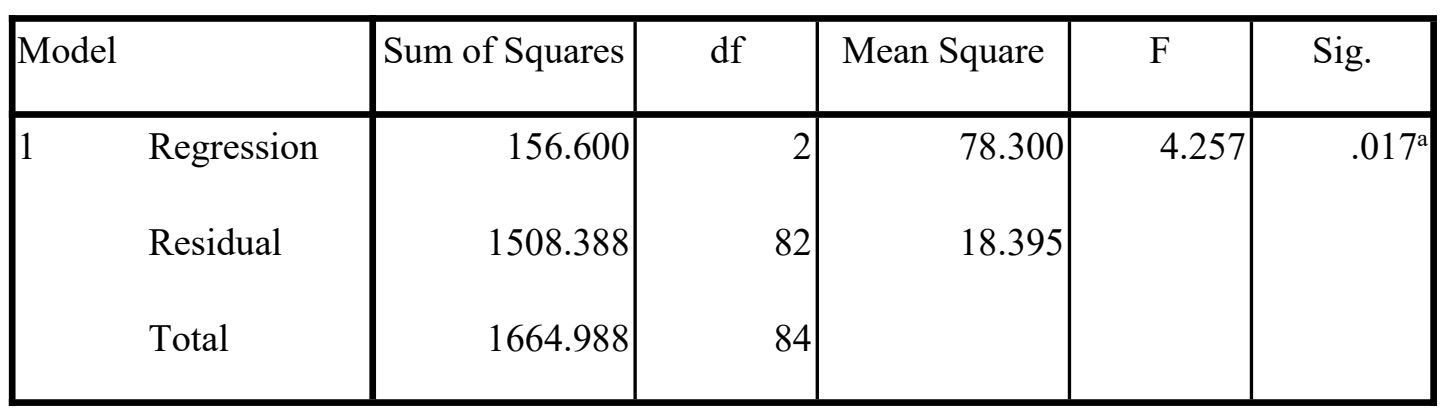

a. Predictors: (Constant), Motivasi, Kreativitas

b. Dependent Variable: Kemandirian

Berdasarkan hasil output diatas, diketahui nilai sig. adalah 0,017. Karena nilai sig. 0,017 lebih kecil dari 0,05, maka sesuai dengan dasar pengambilan keputusan dasar dalam uji $\mathrm{F}$ dapat disimpulkan bahwa hipotesis signifikan atau dengan kata lain Kreativitas dan Motivasi secara stimulan berpengaruh terhadap Kemandirian Belajar.

Berdasarkan perbandingan nilai $\mathrm{F}$ hitung dengan $\mathrm{F}$ table. Berdasarkan table output diatas, diketahui nilai $\mathrm{F}$ hitung adalah 4,257. Karena nilai $\mathrm{F}$ hitung 4,257 lebih besar dari F table 3,107, maka sesuai dengan dasar pengambilan keputusan dalam uji $F$ dapat disimpulkan bahwa hipotesis signifikan atau dengan kata lain Kreativitas dan Motivasi secara simultan berpengaruh terhadap Kemandirian Belajar.

\section{Pembahasan}

Penelitian ini dilaksanakan dengan tujuan untuk mengetahui pengaruh kreativitas dan motivasi terhadap kemandirian belajar siswa kelas X diSMA Kristen Satya Wacana. Dalam penelitian ini banyak sampel yaitu 85 orang. Penelitian ini termasuk penelitian kuantitatif. . Penelitian ini menggunakan data yang berupa angka sebagai angka sebagai alat untuk menemukan keterangan mengenai apa yang ingin diketahui. Angka-angka yang terkumpul sebagai hasil penelitian nanti dapat dianalisis dengan metode statistika.

Berdasarkan hasil pengujian menggunakan uji $\mathrm{t}$ diperoleh hasil bahwa kreativitas tidak berpengaruh terhadap kemandirian belajar. Hal ini dapat diketahui dari nilai uji $\mathrm{t}$ hitung kreativitas ialah 0,159 dengan nilai signifikan 0,05. Berdasarkan hal ini, maka hipotesis pertama yaitu "Kreativitas tidak berpengaruh terhadap Kemandirian belajar" terbukti kebenarnya.

Hasil penelitian ini tidak sejalan dengan hasil dalam temuan yang dilakukan oleh (1) Isnawati (2013) yang meneliti mahasiswa pada Fakultas Keguruan dan Ilmu Pendidikan di Universitas Muhammadiyah Surakarta. Hasil penelitian ini menunjukkan bahwa Kreativitas 
berpengaruh terhadap Kemandirian Belajar. (2) Muslimah (2014) yang meneliti siswa pada mata pelajaran ekonomi kelas VIII SMP Negeri 2 Sawit. Hasil penelitian ini menunjukkan bahwa Kemandirian berpengaruh terhadap Kreativitas siswa kelas VIII SMP Negeri 2 Sawit. Hal ini menjelaskan bahwa Kreativitas terkadang tidak selalu berpengaruh baik terhadap Kemandirian belajar siswa.

Berdasarkan hasil pengujian menggunakan uji t diperoleh hasil bahwa motivasi berpengaruh terhadap kemandirian belajar. Hal ini dapat diketahui dari nilai uji t hitung 0,018 dengan nilai signifikan 0,05. Berdasarkan hal ini, maka hipotesis kedua yang berbunyi "Motivasi berpengaruh terhadap Kemandirian belajar" terbukti kebenarannya.

Hasil analisis menunjukkan adanya pengaruh motivasi terhadap kemandirian belajar. Artinya semakin tinggi motivasi siswa maka akan semakin tinggi kemandirian belajar. Dengan kata lain, kemandirian belajar dapat dibentuk dengan adanya motivasi yang dimiliki oleh siswa. Oleh karena itu apabila ingin meningkatkan kemandirian belajar siswa, maka perlu memperhatikan sejauh mana siwa mendapat dorongan yang akan menjadikan motivasinya dalam belajar. Hasil dalam penelitian ini sejalan dengan hasil dalam temuan penelitian yang telah dilakukan oleh (1) Isnawati 2013 yang meneliti mahasiswa Fakultas Keguruan dan Ilmu Pendidikan di Universitas Muhammadiyah Surakarta. Hasil penelitian ini menunjukkan bahwa siswa lebih termotivasi dalam belajar guna untuk meningkatkan kemandirian belajar mereka. (2) Muslimah (2014) yang meneliti siswa pada mata pelajaran ekonomi kelas VIII SMP Negeri 2 Sawit. Hasil penelitian ini menunjukkan bahwa motivasi berpengaruh terhadap kreativitas siswa kelas VIII SMP Negeri 2 Sawit. . Hal ini menjelaskan bahwa Motivasi dapat berpengaruh terhadap Kemandirian Belajar bagi para siswa. Hasil analisis menunjukkan variable Kreativitas dan Motivasi secara simultan berpengaruh seara signifikan terhadap Kemandirian Belajar. Hal ini diketahui dari hasil uji $\mathrm{F}$ yang menunjukkan bahwa nilai $\mathrm{F}$ hitung ialah 4,257 sedangkan nilai $\mathrm{F}$ table ialah 3,107 dengan nilai signifikan 0,05 . Sehingga dapat disimpulkan bahwa terdapat pengaruh antara Kreativitas dan Motivasi terhadap Kemandirian belajar pada siswa kelas X diSMA Kristen Satya Wacana. Dengan demikian hipotesis ketiga penelitian yaitu "kreativitas dan motivasi berpengaruh terhadap kemandirian belajar" adalah terbukti kebenarnya.

Hasil dalam penelitian ini sejalan dengan hasil penelitian yang telah dilakukan oleh (1) Isnawati (2013) yang meneliti mahasiswa pada Fakultas Keguruan dan Ilmu Pendidikan di Universitas Muhammadiyah Surakarta yang memperoleh hasilnya menunjukkan bahwa kreativitas dan motivasi berpengaruh terhadap kemandirian belajar. (2) Muslimah (2014) yang meneliti siswa pada mata pelajaran ekonomi kelas VIII SMP Negeri 2 Sawit yang memiliki hasil adanya pengaruh antara kemandirian dan motivasi terhadap kreativitas siswa kelas VIII SMP Negeri 2 Sawit. Hal ini menunjukkan bahwa ketika Kreativitas diseimbangkan dengan Motivasi secara bersama-sama dapat berpengaruh baik guna untuk meningkatkan Kemandirian Belajar siswa.

\section{Simpulan dan Saran}

Penelitian ini diperoleh hasil dan pembahasan yang telah diuraikan, maka dapat diambil beberapa kesimpulan yaitu : secara parsial inflasi tidak berpengaruh signifikan terhadap kemandirian belajar pada kreativitas karena dilihat dari hasil uji $t$ tidak berpengaruh signifikan dengan nilai signifikan 0,159 yang lebih besar dari kriteria 
signifikansi yaitu 0,05. Secara parsial Motivasi berpengaruh terhadap kemandirian belajar karena dapat dilihat dari hasil uji t motivasi memiliki nilai signifikansi 0,018 lebih kecil dari kriteria signifikansi yaitu 0,05. Sedangkan secara stimulan maka Kreativitas dan Motivasi memiliki pengaruh signifikan terhadap Kemandirian Belajar. Karena diperoleh nilai hitung 4,257 lebih besar dari $\mathrm{F}$ table 3,107, sedangkan diperoleh nilai signifikansinya sebesar 0,017 yang artinya lebih kecil dari 0,05 .

Bagi siswa SMA Kristen Satya Wacana agar dapat meningkatkan kemandirian belajarnya baik di sekolah maupun di luar sekolah secara mandiri dan bertanggung jawab. Bagi guru agar dapat memberikan informasi dan pengetahuan untuk meningkatkan siswa untuk lebih mandiri dalam kegiatan belajar di sekolah. Bagi peneliti selanjutnya dapat melanjutkan penelitian yang sama dengan melihat faktor-faktor lain yang terdapat di dalam kemandirian belajar siswa.

\section{Daftar Rujukan}

A.M. Sardiman. (2007). Interaksi dan Motivasi Belajar Mengajar. Jakarta : Raja Grafindo Persada.

Azwar, Saifuddin. (2007). Metode Penelitian. Pustaka Pelajar. Yogyakarta.

Conny R. Semiawan. (2008). Keativitas Anak Usia Dini. Jakarta : Macan Jaya Cemerlang.

Ghozali, Imam. (2013). Aplikasi Analisis Multivariate dengan Program SPSS Edisi Ketujuh. Semarang. Badan Penerbit Universitas Diponegoro.

Hanafi Muslimah. (2014). Pengaruh Kemandirian belajar dan Motivasi belajar terhadap Kreativitas belajar siswa pada mata pelajaran ekonomi kelas VIII SMP Negeri 2 Sawit tahun ajaran 2013/2014.

Hamzah B. Uno. (2011). Teori Motivasi dan Pengukurannya : Analisis di Bidang Pendidikan Jakarta : Bumi Askara.

Haris Mudjiman. (2011). Manajemen Pelatihan berbasis belajar mandiri. Yogyakarta. Pustaka Pelajar.

Moh. Nazr. (2011). Metode Penelitian. Bogor : Penerbit Ghalia Indonesia.

Nina Ismawati. (2013). Kemandirian ditinjau dari Kreativitas Belajar dan Motivasi belajar pada mahasiswa Fakultas Keguruan Dan Ilmu Pendidikan Universitas Muhammadiyah Surakarta angkatan 2010/2011.

Noor Syam. Moh. (1983). Filsafat Pendidikan dan Filsafat Pendidikan Pancasila. Surabaya: : Usaha Nasional.

Nurgiyontoro, Burhan. (2013). Penelitian Pembelajaran Bahasa Berbasis Kompetensi. Yogyakarta : Badan Percetakan Fakultas Ekonomi Universitas Negeri Yogyakarta.

Rahardja, Umar Tirta. La Sulo.(2000). Pengantar Pendidikan. Jakarta: Rineka Cipta..

Rivai, Veithzal dan Sagala, Ella Jauvani. (2009). Manajemen Sumber Daya Manusia untuk Perusahaan dan Teori dan Praktik. Jakarta : PT Raja.

Sugiyono. (2013). Metode Penelitan Kuantitatif, Kualitatif, dan R\&D. Bandung : Alfabeta.CV. 
Suwarto, D. (2013). Pengembangan Tes Diagnostik Dalam Pembelajaran. Yogyakarta: Pustaka Pelajar.

Suwarto, S. (2017). Pengembangan tes ilmu pengetahuan alam terkomputerisasi. Jurnal Penelitian dan Evaluasi Pendidikan, 21(2), 153-161.

Utami Munandar. (2009). Pengembangan Kreativitas Anak Berbakat. Bandung : Rineka Cipta.

Yonada Dwi Kaputri. (2018). Pengaruh Emosional, Movitasi, Kreativitas dan Gaya Belajar terhadap Kemandirian Belajar mata pelajaran IPS pada siswa kelas VII dan VIII SMP Bina Mulya Bandar Lampung tahun pelajaran 2017/2018.

Yustika Wijaya. (2019). Pengaruh Efikasi Diri, Kreativitas, Cara Belajar terhadap Kemandirian Belajar Melalui Motivasi Belajar Mata Pelajaran Ekonomi pada siswa X SMA Negeri 1 Palas Tahun Pelajaran 2018/2019 